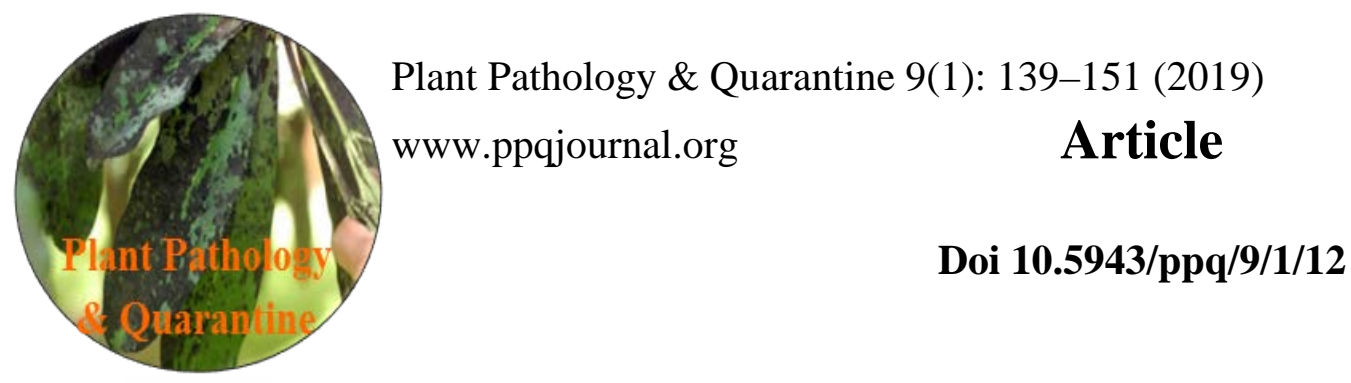

ISSN 2229-2217

\title{
The plant pathogenic genus Neocordana
}

\section{Samarakoon $S M B C^{1,2}$, Wanasinghe $\mathrm{DN}^{3,5}$, Jeewon $\mathrm{R}^{4}$, Tian $\mathbf{Q}^{1,5}$, Jayawardena RS $^{1}$ and Chomnunti $\mathbf{P}^{2^{*}}$}

\footnotetext{
${ }^{1}$ Center of Excellence in Fungal Research, Mae Fah Luang University, Chiang Rai, 57100, Thailand

${ }^{2}$ School of Science, Mae Fah Luang University, Chiang Rai, 57100, Thailand

${ }^{3}$ World Agro Forestry Centre, East and Central Asia, 132 Lanhei Road, Kunming 650201, Yunnan, China

${ }^{4}$ Department of Health Sciences, Faculty of Science, University of Mauritius, Reduit, Mauritius

${ }^{5}$ Key Laboratory for Plant Biodiversity and Biogeography of East Asia (KLPB), Kunming Institute of Botany, Chinese Academy of Science, Kunming 650201, Yunnan, China
}

Samarakoon SMBC, Wanasinghe DN, Jeewon R, Tian Q, Jayawardena RS, Chomnunti P 2019 The plant pathogenic genus Neocordana. Plant Pathology \& Quarantine 9(1), 139-151, Doi 10.5943/ppq/9/1/12

\begin{abstract}
Neocordana species mainly causes leaf spots on Musa spp. (banana and plantain) and on Canna denudata (an ornamental plant). Leaf spots on Musa spp. reduce the quality of the commodity and result in significant economic loss. Based on molecular and morphological data, the genus accommodates seven species at present with a worldwide distribution. Most of the taxonomic work has been conducted on Neocordana musae. In this study, updates on the diversity, distribution, and morpho-molecular taxonomy of Neocordana are provided. In addition, important aspects such as pathogenicity, disease control, antagonistic activity and association with other pathogenic fungi are discussed. The phylogenetic relationships of Neocordana with other genera in the family Pyriculariaceae based on LSU and ITS DNA sequence data are investigated. Our results support the monophyletic nature of Neocordana which is sister to Barretomyces. This study provides the first comprehensive account on diversity, taxonomy, and pathogenicity of Neocordana.
\end{abstract}

Keywords - antagonistic - banana - controlling - endophytic - pathogens - Pyriculariaceae

\section{Introduction}

Fungi are organisms that play various ecological roles in the environment, including decomposition of organic matter, recycling of nutrients, and exhibit pathogenic and endophytic lifestyles (Tang et al. 2005, Treseder \& Lennon 2015, Rampadarath et al. 2018, Wanasinghe et al. 2018b). The asexual genus, Neocordana was established by Hernández-Restrepo et al. (2015) and accommodated in the family Pyriculariaceae, order Magnaporthales. Neocordana musae (Zimm.) Hern.-Restr. \& Crous is the type species (Hernández-Restrepo et al. 2015) and seven plant pathogenic and saprobic taxa (Index Fungorum 2019) are included in the genus from a limited number of hosts (Musaceae and Cannaceae) worldwide (Jones 1999, Hernández-Restrepo et al. 2015, Crous et al. 2016, 2017, 2019) (Table 1). Several studies have reported that fungi can exhibit different lifestyles such as endophytes, saprobes or pathogens (Promputtha et al. 2007, Maharachchikumbura et al. 2011, Jeewon et al. 2013). Neocordana is an excellent example for a 
fungal genus that represents all three modes of ecological strategies, notably, as a plant pathogen and saprobe (Hernández-Restrepo et al. 2015, Crous et al. 2016, 2017, 2019), as well as an endophyte (Photita et al. 2001). As plant pathogens, the overwhelming majority of species causes leaf spots on Musa spp. (banana) (Allen \& Dettmann 1990, Jones 1999, Fan et al. 2012). In addition, Neocordana versicolor infects the leaves of Canna denudata, a common ornamental plant in Brazil (Soares et al. 2005). The damage caused by the pathogens is severe, resulting in major defoliation (Hernández-Restrepo et al. 2015) and minimize the rate of photosynthesis in host plants. Generally, the leaf spots, resulting from the pathogen can affect the productivity, quality and the market value of commodities (Gaikwad et al. 2017) and contribute to considerable economic loss. The objectives of this study are to i) provide an updated account of the diversity, distribution and morpho-molecular taxonomy of the genus Neocordana; ii) reinvestigate intergeneric relationships of Neocordana based on LSU and ITS sequence data; iii) discuss the pathogenicity aspects, potential of disease control and endophytic nature of Neocordana.

Table 1 Recorded species of Neocordana, hosts and distribution.

\begin{tabular}{|c|c|c|c|}
\hline Species & Host & Distribution & Reference \\
\hline $\begin{array}{l}\text { Neocordana johnstonii (M.B. } \\
\text { Ellis) Hern.-Restr. \& Crous }\end{array}$ & Musa sapientum & $\begin{array}{l}\text { Australia, Indonesia } \\
\text { Malaysia, Philippines, } \\
\text { Tonga }\end{array}$ & $\begin{array}{l}\text { Hernández-Restrepo et al. } \\
\text { (2015) }\end{array}$ \\
\hline N. malayensis Crous & Musa sp. & Malaysia & Crous et al. (2019) \\
\hline $\begin{array}{l}\text { N. musae (Zimm.) Hern.- } \\
\text { Restr. \& Crous }\end{array}$ & Musa sapientum & $\begin{array}{l}\text { Has been recorded } \\
\text { around the tropical } \\
\text { region }\end{array}$ & $\begin{array}{l}\text { Hernández-Restrepo et al. } \\
\text { (2015) }\end{array}$ \\
\hline N. musarum Crous & Musa sp. & France & Crous et al. (2016) \\
\hline $\begin{array}{l}\text { N. musicola Hern.-Restr. \& } \\
\text { Crous }\end{array}$ & Musa sp. & Mauritius, Mexico & $\begin{array}{l}\text { Hernández-Restrepo et al. } \\
\text { (2015) }\end{array}$ \\
\hline N. musigena Crous & Musa sp. & Morocco & Crous et al. (2017) \\
\hline $\begin{array}{l}\text { N. versicolor (D.J. Soares \& } \\
\text { R.W. Barreto) Hern.-Restr. \& } \\
\text { Crous }\end{array}$ & Canna denudata & Brazil & $\begin{array}{l}\text { Hernández-Restrepo et al. } \\
\text { (2015) }\end{array}$ \\
\hline
\end{tabular}

\section{Diversity, distribution, and morphology}

The sexual morph of Neocordana species is still unknown (Hernández-Restrepo et al. 2015, Crous et al. 2016, 2017, 2019) while the asexual morphs are brown hyphomycetes with differentiated conidiophores which are straight, and erect. Conidiophores bear pale brown conidia that arise from the terminal and intercalary conidiogenous cells (Hernández-Restrepo et al. 2015). Colonies are usually grown on potato dextrose agar (PDA). The mycelia are superficial, hairy and grey to brown. This mycelial growth has also been recorded on the cuticle of host plants. The septate mycelia are hyaline and become brown with age (Hernández-Restrepo et al. 2015). The morphological features of $N$. musae are illustrated in Fig. 1. The main morphological characters (especially conidial size and shape) differentiating species of genus Neocordana are outlined in Tables 2, 3, 4 and 5.

Neocordana versicolor can be delineated from N. musae in terms of conidial shape, colour and size (Table 3) while $N$. johnstonii and $N$. versicolor also bear some morphological dissimilarities in the conidiophore (Table 4). When comparing $N$. musae and $N$. johnstonii, the conidiophores of both taxa are brown, erect, straight, septate and denticulate. The conidiophores arise as single small groups and paler towards the apex in color. Conidia of both organisms are twocelled, smooth and pale brown to hyaline. A thickened hylum can be seen in conidia. Colonies are hypophyllous, effuse to hairy and dark brown. The size of conidiophores and conidia are different from each other as listed in Table 5 (Jones 1999). 


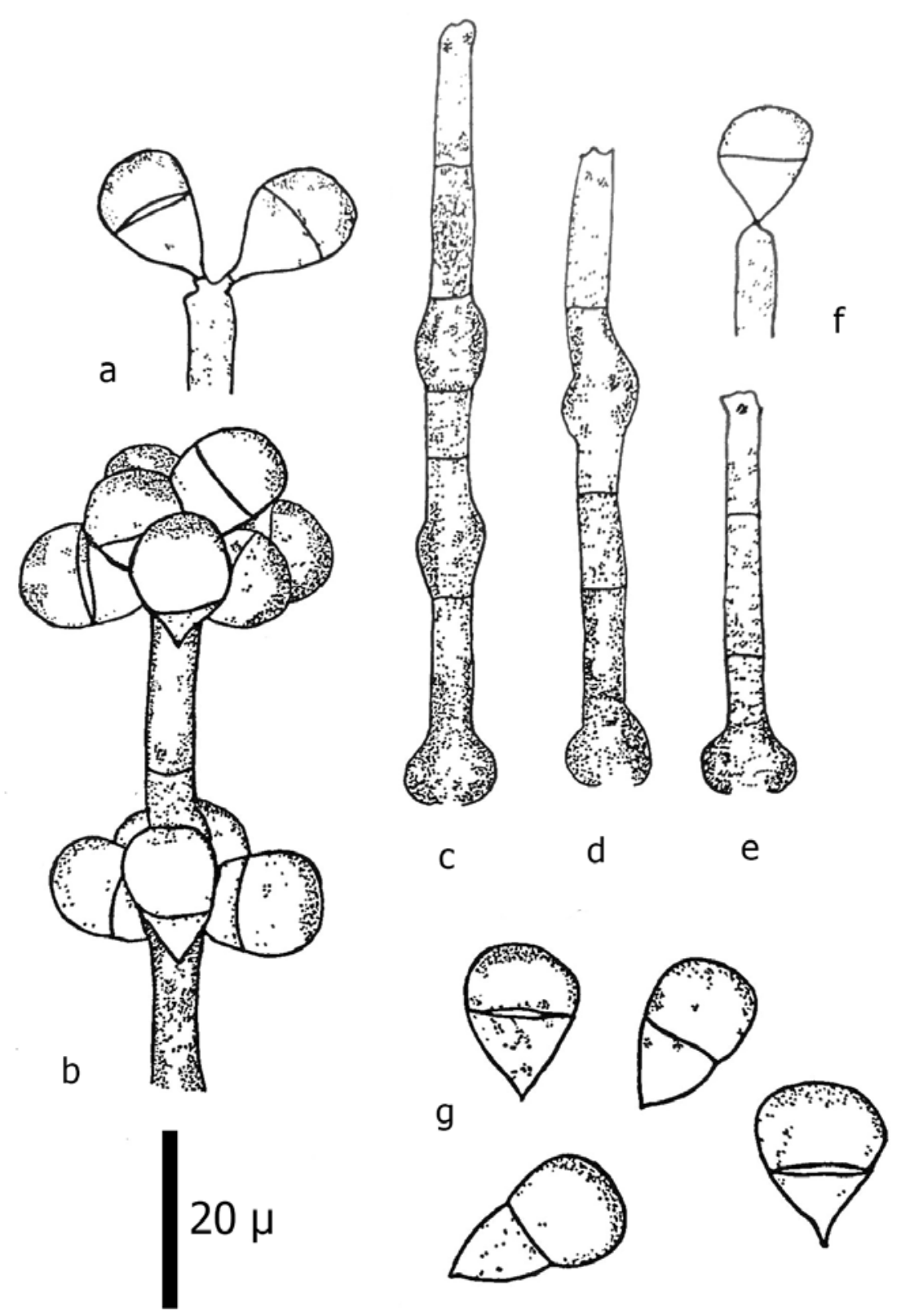

Fig. 1 - Neocordana musae. a, b, f Conidiophores with attached conidia. c, d, e Conidiophores from which conidia are detached. g Conidia (redrawn from Meredith (1962b).

Table 2 Comparison of the size and shape of conidia in Neocordana.

\begin{tabular}{|c|c|c|c|}
\hline Taxa & Shape of the conidia & Size of the conidia & Reference \\
\hline $\begin{array}{l}\text { Neocordana } \\
\text { johnstonii }\end{array}$ & Ellipsoidal to subglobose & $19-26 \times 14-16 \mu \mathrm{m}$ & $\begin{array}{l}\text { Hernández-Restrepo et al. } \\
\text { (2015) }\end{array}$ \\
\hline N. malayensis & oblong to obovoid & $14-18 \times 8-10 \mu \mathrm{m}$ & Crous et al. (2019) \\
\hline N. musae & Obclavate to pyriform & $14-18 \times 8-10 \mu \mathrm{m}$ & $\begin{array}{l}\text { Hernández-Restrepo et al. } \\
\text { (2015) }\end{array}$ \\
\hline N. musarum & Oblong to obovoid & $15-20 \times 9-13 \mu \mathrm{m}$ & Crous et al. (2016) \\
\hline N. musicola & Oblong to obovoid & $14.5-20 \times 6.5-9.5$ & $\begin{array}{l}\text { Hernández-Restrepo et al. } \\
\text { (2015) }\end{array}$ \\
\hline N. musigena & Oblong to obovoid & $15-18 \times 7-9 \mu \mathrm{m}$ & Crous et al. (2017) \\
\hline N. versicolor & Ellipsoidal & $15-25 \times 10-15 \mu \mathrm{m}$ & $\begin{array}{l}\text { Hernández-Restrepo et al. } \\
\text { (2015) }\end{array}$ \\
\hline
\end{tabular}


Table 3 Morphological differences between Neocordana musae and N. versicolor.

\begin{tabular}{lll}
\hline Character & Neocordana musae & Neocordana versicolor \\
\hline Appressoria & Dark grey & Dark brown \\
Conidia & Broadly ellipsoid & Obovoid to pyriform \\
Family of the host & Musaceae & Cannaceae \\
Germ tube & End with amulliform & Shaped a boxing glove \\
\hline
\end{tabular}

Table 4 Distinct features of the conidiophore between N. johnstonii and N. versicolor.

\begin{tabular}{lll}
\hline $\begin{array}{l}\text { Character of the } \\
\text { conidiophore }\end{array}$ & Neocordana johnstonii & Neocordana versicolor \\
\hline $\begin{array}{l}\text { Apical and intercalary part } \\
\text { Presence of denticles }\end{array}$ & $\begin{array}{l}\text { Not swollen } \\
\text { More than one denticle at the } \\
\text { swollen parts }\end{array}$ & $\begin{array}{l}\text { Becomes bulbous and swollen } \\
\text { One denticle per swelling }\end{array}$ \\
\hline
\end{tabular}

Table 5 Comparison of conidia and conidiophores of $N$. musae and $N$. johnstonii.

\begin{tabular}{lll}
\hline Character & Neocordana musae & Neocordana johnstonii \\
\hline Conidiophore & Often nodose & Often twisted in the basal part \\
& Up to $150 \mu$ m long & Up to $300 \mu$ long \\
& $4-6 \mu \mathrm{m}$ in diameter & $5-9 \mu \mathrm{m}$ in diameter \\
Conidia & Short & Longer and wider than $N$. Musae \\
\hline
\end{tabular}

Crous et al. (2016) mentioned that $N$. musarum resembles $N$. musae. Size of the conidia can be used to differentiate between the two species, as $N$. musarum has wider conidia than $N$. musae. According to Crous et al. (2017), N. musigena is similar to $N$. musicola but phylogenetically distinct. Crous et al. (2019) mentioned that some of the morphological features of $N$. malayensis (such as conidial dimensions) overlap with N. musae and N. musicola. Neocordana malayensis can be separated from other Neocordana species as it has very long, flexuous conidiophores and the phylogenetic distinct.

Fungal colony characters of species in the genus are almost similar and only a few contrasting features were noticed and these are detailed in Table 6.

Table 6 Comparison of culture characteristics in Neocordana.

\begin{tabular}{|c|c|c|c|}
\hline \multirow[t]{2}{*}{ Species } & \multicolumn{2}{|l|}{ Colonies on Malt Extract Agar (MEA) } & \multirow[t]{2}{*}{ Reference } \\
\hline & Upper surface of the plate & $\begin{array}{l}\text { Lower surface } \\
\text { of the plate }\end{array}$ & \\
\hline $\begin{array}{l}\text { Neocordana } \\
\text { johnstonii }\end{array}$ & In vitro cultures are not available & $\begin{array}{l}\text { In vitro cultures } \\
\text { are not available }\end{array}$ & $\begin{array}{l}\text { Hernández- } \\
\text { Restrepo et al. } \\
\text { (2015) }\end{array}$ \\
\hline $\begin{array}{l}N . \\
\text { malayensis }\end{array}$ & $\begin{array}{l}\text { Flat, spreading with moderate, aerial mycelium, } \\
\text { having a feathery margin. dirty white surface having } \\
\text { patches of pale olivaceous grey or pale luteous in } \\
\text { colour }\end{array}$ & Not mentioned & $\begin{array}{l}\text { Crous et al. } \\
\text { (2019) }\end{array}$ \\
\hline N. musae & $\begin{array}{l}\text { Elevated and cottony, aerial mycelium is white, mouse } \\
\text { gray zones represent the sporulation, having a defuse } \\
\text { margin }\end{array}$ & $\begin{array}{l}\text { Centre is black, } \\
\text { have concentric } \\
\text { rings, isabelline } \\
\text { to umber or } \\
\text { luteous to } \\
\text { ochreous in } \\
\text { colour }\end{array}$ & $\begin{array}{l}\text { Hernández- } \\
\text { Restrepo et al. } \\
\text { (2015) }\end{array}$ \\
\hline
\end{tabular}


Table 6 Continued.

\begin{tabular}{|c|c|c|c|}
\hline \multirow{2}{*}{ Species } & \multicolumn{2}{|l|}{ Colonies on Malt Extract Agar (MEA) } & \multirow{2}{*}{ Reference } \\
\hline & Upper surface of the plate & $\begin{array}{l}\text { Lower surface } \\
\text { of the plate }\end{array}$ & \\
\hline N. musarum & $\begin{array}{l}\text { Colonies are flat and spreading, aerial mycelium is } \\
\text { moderate and smooth, having even margins, dirty } \\
\text { white in colour }\end{array}$ & $\begin{array}{l}\text { Pale luteous in } \\
\text { colour }\end{array}$ & $\begin{array}{l}\text { Crous et al. } \\
\text { (2016) }\end{array}$ \\
\hline N. musicola & $\begin{array}{l}\text { Cottony, aerial mycelium is white and mouse grey } \\
\text { towards the edge that shows the sporulation, having a } \\
\text { diffuse margin }\end{array}$ & $\begin{array}{l}\text { Fuscous black in } \\
\text { the center, } \\
\text { luteous at the } \\
\text { edge }\end{array}$ & $\begin{array}{l}\text { Hernández- } \\
\text { Restrepo et al. } \\
\text { (2015) }\end{array}$ \\
\hline N. musigena & $\begin{array}{l}\text { Colonies flat, spreading, with moderate aerial } \\
\text { mycelium, and feathery margins }\end{array}$ & $\begin{array}{l}\text { Luteous in } \\
\text { colour }\end{array}$ & $\begin{array}{l}\text { Crous et al. } \\
\text { (2017) }\end{array}$ \\
\hline N. versicolor & In vitro cultures are not available & $\begin{array}{l}\text { In vitro cultures } \\
\text { are not available }\end{array}$ & $\begin{array}{l}\text { Hernández- } \\
\text { Restrepo et al. } \\
\text { (2015) }\end{array}$ \\
\hline
\end{tabular}

\section{History and taxonomy of Neocordana}

Neocordana species were classified under the asexual dematiaceous hyphomycetes genus Cordana Preuss. Cordana was established by Preuss (1851) with C. pauciseptata Preuss as the type specimen. It was characterized by brown conidiophores which are septate, bearing swollen conidiogenous zones. Cordana consisted of saprobic and pathogenic species. Saprobes use soil and rotten wood as substrates whereas pathogens colonize leaves. With DNA sequence data and phylogenetic concepts, pathogens such as $C$. musae, $C$. johnstonii and $C$. versicolor were placed in the order Magnaporthales, family Pyriculariaceae and accommodated in Neocordana.

Hernández-Restrepo et al. (2015) provided a phylogenetic tree based on analyses of LSU and ITS sequence data of $N$. musae and $N$. musicola isolates with other taxa of Magnaporthales. The isolates of $N$. musae and $N$. musicola were from different localities such as Australia, Mauritius, Malaysia and Mexico (Hernández-Restrepo et al. 2015). With high bootstrap support, Neocordana isolates were clearly separated as a monophyletic clade in Pyriculariaceae. DNA sequence data of $N$. versicolor and $N$. johnstoni are not available and therefore not included in the phylogenetic analysis. Based on the morphological data and host pathogenic interactions, $N$. versicolor and $N$. johnstoni were included in the genus. Crous et al. (2016) have introduced $N$. musarum as a new species with the help of descriptive, morphological and molecular data (Bayesian analysis of the LSU sequences). Next species introduced by Crous et al. (2017) is N. musigena. Crous et al. (2019) recently introduced $N$. malayensis based on LSU sequence data. The taxonomic placement of five species ( $N$. musae, $N$. musicola, $N$. musarum, $N$. musigena and $N$. malayensis) are supported by molecular data but the taxonomic placement of two species ( $N$. versicolor and $N$. johnstoni) are still uncertain due to the lack of molecular data. Currently, LSU, ITS, ACT, and RPB1 gene sequences are available in GenBank for the recently introduced above mentioned four species. The published record for $N$. versicolor was provided by Soares et al. (2005) and its establishment was mainly based on morphology, plant family of the host and pathogenicity.

\section{Taxonomic placement of the genus Neocordana in the family Pyriculariaceae}

In this study, we present an updated tree of the Pyriculariaceae by using all the available LSU and ITS sequences. Multiple alignments were automatically done by MAFFT v. 7.036 (http://mafft.cbrc.jp/alignment/server/index.html; Katoh \& Standley 2013) using BioEdit v. 7.0.5.2 (Hall 1999). Maximum likelihood trees were generated using the RAxML-HPC2 on XSEDE (8.2.8) (Stamatakis 2014) in the CIPRES Science Gateway platform (Miller et al. 2010) using the GTR $+\mathrm{I}+\mathrm{G}$ model of evolution. Maximum Likelihood bootstrap values (ML) equal to or greater than $60 \%$ are given above each node in blue (Fig. 2). The parameters as set by Wanasinghe et al. (2018a) were used to conduct the Bayesian analysis. Branches with Bayesian posterior probabilities 
greater than 0.95 above each node in blue (Fig. 2). Phylograms were visualized with FigTree v1.4.0 program (Rambaut 2012) and reorganized in Microsoft power point (2010). 38 taxa that have been used in the study are shown in Table 7. Alignment data and phylogenetic tree are submitted to TreeBASE (www.treebase.org, S23711).

Table 7 Taxa used in the phylogenetic analysis of Pyriculariaceae and their corresponding GenBank accession numbers. Type species of each genus are in bold.

\begin{tabular}{|c|c|c|c|}
\hline \multirow[t]{2}{*}{ Species } & \multirow{2}{*}{$\begin{array}{l}\text { Culture accession } \\
\text { numbers }\end{array}$} & \multicolumn{2}{|c|}{ Gene bank accession numbers } \\
\hline & & LSU & ITS \\
\hline Bambusicularia brunnea & CBS 133599 & KM484948 & KM484830 \\
\hline Barretomyces calatheae & CBS 129274 & KM484950 & KM484831 \\
\hline Gaeumannomyces radicicola & Z 426 AJ & KM484966 & KM484849 \\
\hline G. tritici & CBS 186.65 & KM484955 & KM484838 \\
\hline Macgarvieomyces borealis & CBS 461.65 & DQ341511 & MH858669 \\
\hline M. juncicola & CBS 610.82 & KM484970 & KM484855 \\
\hline Neocordana malayensis & CBS 144604 & MK442533 & MK442593 \\
\hline N. musae & CPC 18127 & LN713290 & NR-154265 \\
\hline N. musae & СРС 16362 & LN713289 & LN713281 \\
\hline N. musae & СРС 16298 & LN713288 & LN713282 \\
\hline N. musae & СРС 19065 & LN713291 & LN713276 \\
\hline N. musarum & СРС 28529 & KY173516 & KY173425 \\
\hline N. musarum & СРС 28525 & KY173515 & KY173424 \\
\hline N. musicola & СРС 15987 & LN713287 & LN713283 \\
\hline N. musicola & СРС 11225 & LN713286 & NR-154266 \\
\hline N. musigena & СРС 29779 & KY979805 & KY979750 \\
\hline N. musigena & СРС 29777 & KY979804 & KY979749 \\
\hline N. musigena & СРС 29140 & KY979803 & KY979748 \\
\hline $\begin{array}{l}\text { Neopyricularia } \\
\text { commelinicola }\end{array}$ & CBS 128303 & KM484982 & KM484868 \\
\hline Proxipyricularia zingiberis & CBS 303.39 & KM484989 & KM484871 \\
\hline $\begin{array}{l}\text { Pseudopyricularia } \\
\text { bothriochloae }\end{array}$ & CBS 136427 & KF777238 & KF777186 \\
\hline P. суреri & CBS 133595 & KM484990 & KM484872 \\
\hline P. hagahagae & СРС 25635 & KT950865 & KT950851 \\
\hline P. higginsii & 09-2007-1470 & KM484991 & KM484875 \\
\hline P. hyrcaniana & Ck2 & KY457266 & NA \\
\hline P. iraniana & $18 d$ & KY457269 & KY465726 \\
\hline P. kyllingae & CBS 133597 & KM484992 & KM484876 \\
\hline P. kyllingae & CB8959 & KM484993 & KM484877 \\
\hline Pyricularia ctenantheicola & GR0001 & KM484994 & KM484878 \\
\hline P. grisea & BR0029 & KM484995 & KM484880 \\
\hline P. oryzae & CBS 365.52 & KM485000 & KM484890 \\
\hline P. oryzae & CBS 375.54 & KM485001 & KM484891 \\
\hline P. penniseticola & BF0017 & KM485031 & KM484925 \\
\hline P. pennisetigena & ML0036 & NA & KM484935 \\
\hline P. urashimae & СРC 29421 & KY173529 & KY173439 \\
\hline P. zingibericola & RN0001 & KM485037 & KM484941 \\
\hline Xenopyricularia zizaniicola & CBS 133593 & NA & KM484947 \\
\hline$X$. zizaniicola & KYZL201-1-1 & KM485042 & KM484946 \\
\hline
\end{tabular}




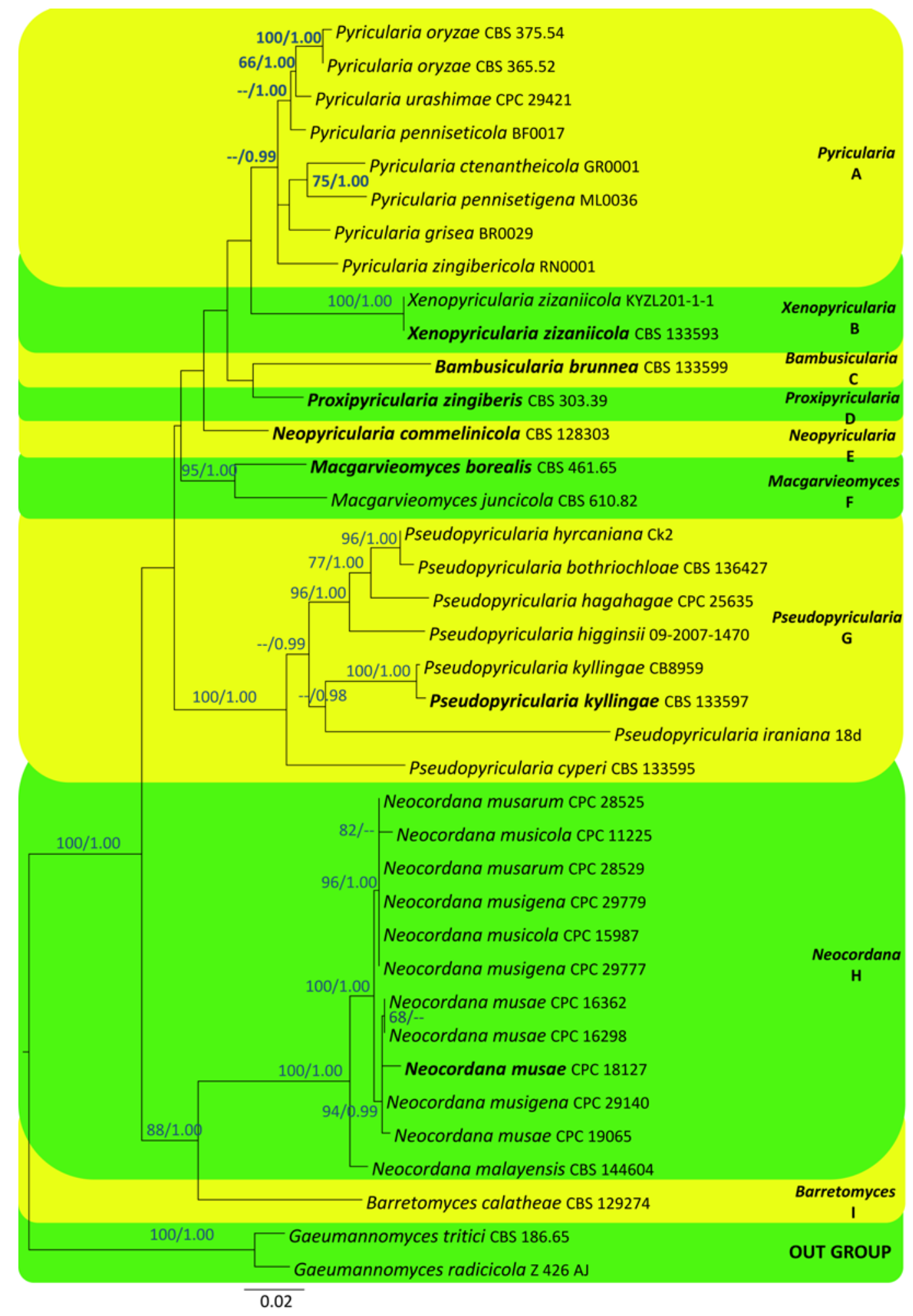

Fig. 2 - Maximum likelihood tree revealed by RAxML from an analysis of combined LSU and ITS partial sequence data of the genera of family Pyriculariaceae, showing the phylogenetic position of the genus Neocordana. ML bootstrap supports $(\geq 60 \%)$ and Bayesian posterior probabilities ( $\geq 0.95 \mathrm{PP}$ ) are given above the branches respectively. The tree is rooted to Gaeumannomyces radicicola and G. tritici (Magnaporthaceae). Type strains of genera are in bold. Estimated base frequencies were as follows; $A=0.248133, C=0.257797, G=0.288552, T=0.205518$; substitution rates $\mathrm{AC}=2.347792, \mathrm{AG}=1.844686$, $\mathrm{AT}=2.746626, \mathrm{CG}=1.125430, \mathrm{CT}=5.574905, \mathrm{GT}$ $=1.000000$; proportion of invariable sites I $=0.566499$; gamma distribution shape parameter $\alpha$ $=0.505155$. The best scoring RAxML tree is shown with a final ML optimization likelihood value of -6111.997 . 
The combined LSU and ITS gene dataset comprised 38 taxa from selected genera of the family Pyriculariaceae and the matrix had 346 distinct alignment patterns, with $13.16 \%$ of undetermined characters or gaps. A total of 36 in group taxa corresponding to 9 monophyletic clades $(\mathrm{ML}=100 \%, \mathrm{PP}=1.00)$, within the Pyriculariaceae is presented herein (Fig. 2). Nine genera previously recognized, namely Bambusicularia (clade C), Barretomyces (clade I, ML = 88\% / PP = 1.00), Macgarvieomyces (clade F, ML = 95\% / PP = 1.00), Neocordana (clade H, ML = 88\% / PP = 1.00), Neopyricularia (clade E), Proxipyricularia (clade D), Pseudopyricularia (clade G)), Pyricularia (clade A) and Xenopyricularia (clade B) are given here. The genus Neocordana constitutes a well-supported monophyletic clade (Clade $\mathrm{H}$ ), sister to $B$. calatheae (clade I). Neocordana taxa were not well separated phylogenetically within the clade, for instance, $N$. musae, N. musicola and N. musigena.

\section{Biology and pathogenicity of Neocordana}

\section{Disease symptoms of Neocordana leaf spots in Musa sp. and Canna denudata}

Neocordana pathogens only target the leaves of the hosts (Jones 1999, Hernández-Restrepo et al. 2015). No published records regarding disease occurrence in other plant parts such as fruits roots or stem are known. Cross infectivity and alteration of hosts are still not observed. The leaf spots on Musa sp. are very common in the field and result in significant crop loss (Jones 1999, Hernández-Restrepo et al. 2015). It was observed that the penetration and the invasion of the Neocordana pathogens are very common during humid environmental conditions (Jones 1999). The severity of the damage depends on the age, nutritional deficiency or the occurrence of previous wounds in the plant. Environmental conditions that the plants are being exposed to also significantly affect the severity of the damage. Neocordana leaf spots on Musa sp. have distinct concentric ring patterns at the gray centers of the necrotic areas (Hernández-Restrepo et al. 2015, Crous et al. 2016). The necrotic lesions are pale brown, large and having an oval to fusiform shape (Jones 1999). Around the brown necrotic area, a bright yellow chlorotic lesion is present and it separates the diseased area of the leaf from the healthy area (Jones 1999). The lesions also can be observed in places where other pathogens had previously invaded. Penetration of the Neocordana pathogens occur at leaf margins and nutrient deficiencies trigger the invasion (Jones 1999, Cooke et al. 2009). The disease symptoms in Canna caused by N. versicolor are also somewhat similar to above (Soares et al. 2005). Eye shaped lesions can be seen in the leaf. They are widely distributed on the surface and finally results in complete necrosis of the leaf (Soares et al. 2005). Leaf spots of $N$. johnstonii were also found to be smaller, more regular in outline and more tapered than $N$. musae. The leaf spots of $N$. musae were recorded as large, elliptical and oval with respect to $N$. johnstonii (Jones 1999).

\section{Ecological factors and the formation of conidia and appressoria}

Violent conidial discharge of Neocordana musae under decreasing vapor pressure at Jamaican plantations of Musa sp. was recorded by Meredith (1962a). In an infected leaf when the relative humidity is lower than 95\%, conidial formation has not been reported. During dry climatic conditions, conidia formation was only recorded at night. Dispersal of conidia was high when the leaf surface got wet during raining season. Meredith (1962a) concluded that the rain, humidity and irrigation can increase conidial concentration on the leaf. Meredith (1962b) discussed that the discharge of conidia is independent from light. As a result of drying, water evaporates from conidia and the conidiophores. Negative pressure was developed soon after water evaporation and finally, the walls are drawn inward and tension builds up. As a result of releasing the tension, conidia are dispersed away from the conidiophores. The gaseous phase of the terminal cell might provide the energy for the discharge of conidia (Meredith 1962b).

Allen \& Dettmann (1990) observed the production of conidia and appressoria formation of $N$. johnstonii in vitro and was considered as a pathogen causing leaf spots. As recorded in Allen \& Dettmann (1990) several Neocordana leaf spots were observed in cold locations compared to warm 
habitats. Sporulation was rapid on the abaxial surface of the leaf under moist weather conditions. Compared to dead leaves, high sporulation was recorded on living leaves. In young leaf spots, sporulation was highly observed. The spores had a short lifespan on dry leaf surfaces. The sporulation continues at a constant rate at least for five days. The optimum temperature for spore production was $21^{\circ} \mathrm{C}-22^{\circ} \mathrm{C}$. The lowest temperature requirement for the production of spores was $10^{\circ} \mathrm{C}$ on wet leaves. Rate of conidia production was recorded as 0.04 conidia $\mathrm{mm}^{-2}$ of lesion $\mathrm{h}^{-1}$ on dead leaves. Appressoria were formed under $22^{\circ} \mathrm{C}-25^{\circ} \mathrm{C}$ on detached leaves. In addition, the production of spores had a low optimum temperature with respect to Mycosphaerella musae and M. musicola (Allen \& Dettmann 1990). Jones (1999) concluded that $N$. johnstonii was more adapted to cooler environments than $N$. musae.

\section{Disease formation of Neocordana musae}

Disease formation has been widely studied only on $N$. musae. The pathogen can penetrate on living and dead cells of the host. Penetration of the pathogen depends on the health of the tissue hence $N$. musae was recorded as a weak pathogen. The penetration is wound-induced. Invasion usually occurs at leaf margins and the places where the leaf lamina got tear off. Effect of senescence, nutritional deficiencies, adverse environmental conditions, wounds and the lesions caused by other pathogens can felicitate the invasion of $N$. musae (Jones 1999). Conidia of $N$. musae can be germinated on a moisture film on the leaf surface. Within 8 hours after the deposition, appressoria formation starts. The appressoria next give rise to the infection peg which penetrates the epidermal cell. After that, one or few fungal cells are formed and fill the epidermal cell. The infection peg starts to swell next. Finally, the epidermal cells face necrotic cell death and result in pale brown lesions (Jones 1999).

\section{Isolation, culturing, identification and biological characteristics of Neocordana}

Few studies were conducted on isolation, culturing and biology and so far, restricted to $N$. musae. In Gaikwad et al. (2017) the fungus was isolated from the diseased leaves of Musa sp. and grown in different media. The culture morphology and colony diameter were observed with respect to the media that have been used in that study. Potato Dextrose Agar media (PDA), Malt Extract Agar media (MEA), Czapeks dox agar media, Asthana \& Hawkars agar, Richard agar, Kings agar and host leaf extract agar media were used. Among all tested mycelia, growth was not observed in Asthana \& Hawkars agar media and Richard agar media. On other media, the colony is gray to white in colour. Distinct concentric to circular rings at the periphery was observed in PDA and King's agar media. A compact growth was observed in Czapeks dox agar and Kings Agar media. When the organism grew on MEA and Czapek's dox agar media, a sparse growth was seen. Sporulation was observed on MEA media from the periphery of the concentric rings. Highest radial growth was recorded on PDA and MEA while the lowest was observed at Czapeks dox agar media. Pure cultures were taken from single spore isolations. Molecular data were not used to identify the organism and pathogenicity tests were not conducted during the study. For the other Neocordana members, detailed studies of the cultures are yet to be conducted. Colony characteristics were recorded in Hernández-Restrepo et al. (2015) and Crous et al. (2016, 2017).

Pathogenic nature of $N$. musae was also studied on Musa sp. in Yunnan province, China (Fan et al. 2012). Morphological observations were conducted from fungal samples associated with leaf spots and optimum favorable temperature for the growth was recorded as $28{ }^{\circ} \mathrm{C}$ and $\mathrm{pH} 7$. Whole light treatment was identified as a good criterion for mycelium growth and the mycelium grows better in sucrose and carbon-rich media. Yeast extract was figured out as better sources for nitrogen in the media. Pathogen showed a profuse growth on PDA and PSA media and the optimum temperature was recorded as $25^{\circ} \mathrm{C}$ for the sporulation on above media. The lethal temperature for the mycelium of $N$. musae was recorded as $70^{\circ} \mathrm{C}$ and the time of exposure was 30 minutes (Fan et al. 2012).

Endophytic nature of Neocordana members and association with Mycosphaerella sp. 
Neocordana musae was recorded as an endophyte in Thailand (Photita et al. 2001). In-depth study on the endophyte was again conducted by Photita et al. (2004). Pathogenic nature (leaf spots formation) of the endophyte was checked on detached Musa leaves. The isolates used were unable to cause the disease on leaves. Photita et al. (2004) concluded that $N$. musae is latent in the host tissue for a long time before causing the disease. There are no published records on the endophytic nature of other Neocordana members.

Neocordana musae was recorded around the lesions as a result of M. musicola, M. fijiensis and another Mycosphaerella sp. which is responsible for Septoria leaf spot disease (Jones 1999). Another study was conducted in northern Thailand by Kaewjan (2012) on Mycosphaerella species and fungi associated with diseases of Musa sp. which recovered $N$. musae as an endophyte. The authors clearly state that $N$. musae can be a weak pathogen which causes diseases under stressed conditions. The pathogen can stay latent during a long period of time inside the host. Tsigbey (1996) reported that black sigatoka symptoms were associated with a lot of conidia and conidiophores of $N$. musae but unable to collect the spores of M. fijiensis. Tsigbey (1996) also observed $N$. musae at the centers and margins of necrotic leaf tissues. Tsigbey (1996) has stated that future studies are warranted on the pathogenic roles of $N$. musae and its link to the severity of black sigatoka disease on Musa sp.

\section{Antagonistic activity of Neocordana musae}

Antagonistic activity of $N$. musae was investigated in vitro on the growth of Colletotrichum musae (Nuangmek et al. 2008). Neocordana musae was recorded as an endophyte from a wild variety of Musa sp., which significantly reduces the radial growth of mycelium of $C$. musae. In addition, this inhibition occurred due to the competitive nature and faster growth of $N$. musae. As a result, the growth of the mycelium of $C$. musae is also inhibited. Production of secondary metabolites by $N$. musae and a related antagonistic activity was not recorded in (Nuangmek et al. 2008).

\section{Controlling of leaf spots}

Fungicides used for Sigatoka leaf disease and black streak disease in Musa sp. can be used to control Neocordana leaf spots (Jones 1999). Addition of oil with the systemic fungicides use in controlling Sigatoka leaf disease in Musa sp. can enhance the severity of Neocordana spots and no specific controlling method was indicated in this study (Ploetz 2003). Biological control was applied on $N$. musae using Jatropha plant extracts to reduce leaf spot diseases in Musa sp. (Torre \& Tangonan 2008). Extracts of several parts of Jatropha plant such as seeds, young fruits, roots and leaves are very effective to control $N$. musae. Alvindia (2012) evaluated the impact of in vitro application of several biocontrol agents on the mycelium growth of $N$. musae. Selected extracts of plant oils, inorganic salts, Trichoderma harzianum, Bacillus amyloliquefaciens, and Serenade ASO (B. subtilis $1.34 \%$ EC) totally controlled the mycelium development of $N$. musae in 10 weeks (Alvindia 2012). In addition to that, Piper betel oil (60\%), potassium bicarbonate (28\%), garlic oil and capsicum oil (20\%) could limit mycelium growth. Jalander \& Gachande (2013) studied the in vitro efficacy of two fungicides named Captasul (capton-50) and Ridomil gold on mycelium growth of $N$. musae. Different concentrations (50ppm, 100ppm, 150ppm, 200 ppm, 250 ppm, and $300 \mathrm{ppm})$ were used against the pathogen and Captasul (300ppm) was reported as highly toxic and very effective to control $N$. musae. Recently Samuelian (2016) investigated antagonistic activities of $T$. harzianum against the growth of $N$. musae as an integrated disease management approach. At present, almost all the biological control methods are applied on $N$. musae, but similar studies are needed on other Neocordana pathogens.

\section{Possible future studies}

Limited number of studies have been conducted on Neocordana when compared to other plant pathogenic genera such as Colletotrichum, Fusarium and Mycosphaerella which cause diseases in Musa sp. Detailed studies were not conducted and few studies could be included in this 
paper. Host and pathogenic interactions, natural disease resistance mechanisms such as induced systemic resistance (ISR), Systemic Acquired Resistance (SAR) and the associated chemical and physiological changes in host plants can also be studied. Postharvest physiology of infected commodities by Neocordana pathogens can be investigated. The infection process was studied in the past but no recent reports can be found on this aspect. As Musa sp. is one of the major fruit crops, it will be useful to investigate more on its pathogenesis, disease cycle and its epidemiology. It is necessary to come up with more biological control strategies such as integrated pest management approaches in the future to cut down treatment costs.

There are only seven species reported at present but very likely that this genus harbors many more species. We have also observed the establishment of new species based on minute morphological differences which are not conclusive to differentiate species. According to Jeewon \& Hyde (2016), phenotypic variations such as the size or shape of conidia must be considered with caution as they can vary with several environmental factors. Therefore, more molecular studies are warranted for a better understanding of species relationships and reveal the potential of species complexes in the future. There are possibilities for investigations on whether Neocordana endophytes can switch to pathogenic and saprobic lifestyles. We suggest to undertake proteomic studies to characterize proteins associated with pathogenicity and disease formation that will be useful in the future for better taxonomic resolutions and disease control.

\section{Acknowledgements}

This work was supported by the National Research Council of Thailand (NRCT grant No. 256108A3070006). D. N. Wanasinghe would like to thank the CAS President's International Fellowship Initiative (PIFI) for funding his postdoctoral research (number 2019PC0008), the National Science Foundation of China and the Chinese Academy of Sciences for financial support under the following grants: 41761144055, 41771063 and Y4ZK111B01. R. Jeewon is grateful to University of Mauritius \& Mae Fah Luang University for enabling research collaboration. The authors offer their sincere gratitude to Kevin D. Hyde, Milan C. Samarakoon, G. Samarakoon, R. H. Perera, A.S Gunathilaka, Kasun Thambugala and Digvijayini Bundhun for their valuable suggestions and comments.

\section{References}

Allen RN, Dettmann EB. 1990 - Production of conidia and appressoria by Cordana johnstonii on banana. Mycological Research 94, 815-818.

Alvindia DG. 2012 - Inhibitory influence of biocontrol agents, plant oils and an inorganic salt on Mycosphaerella fijiensis and Cordana musae, the causal pathogen of black sigatoka and leaf spot of banana. African Journal of Microbiology Research 6, 4179-4184.

Cooke T, Persley D, House S. (Eds.) 2009 - Diseases of fruit crops in Australia. Csiro publishing.

Crous PW, Wingfield MJ, Burgess TI, Hardy GSJ et al. 2016 - Fungal Planet description sheets: 469-557. Persoonia 37, 218-403.

Crous PW, Wingfield MJ, Burgess TI, Barber PA et al. 2017 - Fungal Planet description sheets: 558-624. Persoonia 38, 240-384.

Crous PW, Schumacher RK, Akulov A, Thangavel R et al. 2019 - New and Interesting Fungi 2. Fungal Systematics and Evolution 3, 57-134.

Fan H, Yang P, Guo Z, Zeng L. 2012 - Pathogen and biological characteristics on Cordana leaf spot of banana Southwest China. Journal of Agricultural Sciences 25, 2089-2092.

Gaikwad CB, Thorat BS, Bhokare KR. 2017 - Isolation, culturing and identification of the fungus Cordana musae (Zimm) Hohn causing leaf spot of banana. Journal of Entomology and Zoology Studies 5, 1646-1648.

Hall TA. 1999 - BioEdit: a user-friendly biological sequence alignment editor and analysis program for Windows 95/98/NT. Nucleic Acids Symposium Series 41, 95-98. 
Hernández-Restrepo M, Groenewald JZ, Crous PW. 2015 - Neocordana gen. nov. the causal organism of Cordana leaf spot on banana. Phytotaxa 205, 229-238.

Index Fungorum. 2019 - http://wwwindexfungorumorg/names/namesasp (accessed April 2019)

Jalander V, Gachande BD. 2013 - In vitro efficacy of fungicides against the growth of leaf spot pathogen (Cordana musae Zimm. Hohn.) of banana. Science Research Reporter 3, 4-6.

Jeewon R, Hyde KD. 2016 - Establishing species boundaries and new taxa among fungi: recommendations to resolve taxonomic ambiguities. Mycosphere 7, 1669-1677.

Jeewon R, Ittoo J, Mahadeb D, Jaufeerally-Fakim Y et al. 2013 - DNA based identification and phylogenetic characterization of endophytic and saprobic fungi from Antidesma madagascariense, a medicinal plant in Mauritius. Journal of Mycology, 2013, 1-10

Jones DR. 1999 - Diseases of banana, Abacá, and Enset. CABI Pub, Wallingford, Oxon, UK, New York.

Maharachchikumbura SS, Guo LD, Chukeatirote E, Bahkali AH, Hyde KD. 2011 - Pestalotiopsismorphology, phylogeny, biochemistry and diversity. Fungal Diversity 50, 167-187.

Kaewjan P, Sittikul C, Cheewangkoon R, Hyde KD, Akarapisan A. 2012 - Mycosphaerella and other fungi associated with banana leaf diseases from Northern Thailand. Chiang Mai University Journal of Natural Sciences 11, 25-32.

Katoh K, Standley DM. 2013 - MAFFT multiple sequence alignment software version 7: improvements in performance and usability. Molecular Biology \& Evolution 30, 772-780.

Meredith DS. 1962a - Dispersal of conidia of Cordana musae (Zimm.) Höhnel in Jamaican banana plantations. Annals of Applied Biology 50, 263-267.

Meredith DS. 1962b - Spore discharge in Cordana musae (Zimm.) Höhnel and Zygosporium oscheoides. Annals of Botany 26, 233-241.

Miller MA, Pfeiffer W, Schwartz T. 2010 - Creating the CIPRES science gateway for inference of large phylogenetic trees. Proceedings of the Gateway Computing Environments Workshop (GCE), November 14, 2010, New Orleans, Louisiana 1-8.

Nuangmek W, McKenzie EHC, Lumyong S. 2008 - Endophytic fungi from wild banana (Musa acuminata Colla.) works against anthracnose disease caused by Colletotrichum musae. Research Journal of Microbiology 3, 368-374.

Photita W, Lumyong S, Lumyong P, McKenzie EHC, Hyde KD. 2004 - Are some endophytes of Musa acuminata latent pathogens? Fungal Diversity 16, 131-140.

Photita W, Lumyong S, Lumyong P. 2001 - Endophytic fungi of wild banana (Musa acuminata) at Doi Suthep Pui National Park, Thailand. Mycological Research 105, 1508-1513.

Ploetz RC. 2003 - Diseases of tropical fruit crops. CABI.

Preuss GT. 1851 - Synopsis fungorum cognitorum praesertim prope Hoyerswerda. Linnaea 24, 101-153.

Promputtha I, Lumyong S, Dhanasekaran V, McKenzie EHC et al. 2007 - A phylogenetic evaluation of whether endophytes become saprotrophs at host senescence. Microbial Ecology 53, 579-590.

Rambaut A. 2012 - FigTree v 140 Available at: http://treebioedacuk/software/figtree/

Rampadarath S, Bandhoa K, Puchooa D, Jeewon R, Bal S. 2018 - Metatranscriptomics analysis of mangroves habitats around Mauritius. World Journal of Microbiology and Biotechnology 34, 59.

Samuelian S. 2016 - Potential of Trichoderma harzianum for control of banana leaf fungal pathogens when applied with a food source and an organic adjuvant. 3 Biotech 6, 1-11.

Soares DJ, Nechet KL, Barreto RW. 2005 - Cordana versicolor sp. nov. (dematiaceous hyphomycete) causing leaf-spot on Canna denudata (Cannaceae) in Brazil, with observations on Cordana musae. Fungal Diversity 18, 147-155.

Stamatakis A. 2014 - RAxML version 8: a tool for phylogenetic analysis and post-analysis of large phylogenies. Bioinformatics 30, 1312-1313. 
Tang AMC, Jeewon R, Hyde KD. 2005 - Successional patterns of micro fungi in fallen leaves of Castanopsis fissa (Fagaceae) in Hong Kong forest. Canadian Journal of Microbiology 51, 967-974.

Torre ACD, Tangonan NG. 2008 - Efficacy of Jatropha extracts against Cordana musae causing leafspot of Cardava banana. USM R\&D Journal 16, 89-97.

Treseder KK, Lennon JT. 2015 - Fungal traits that drive ecosystem dynamics on land. Microbiology and Molecular Biology Reviews 79, 243-262.

Tsigbey FK. 1996 - Isolation, identification and pathogenicity of fungal pathogen (s) causing Black Sigatoka disease of local plantain and banana in Ghana. (Doctoral dissertation, University of Ghana).

Wanasinghe DN, Jeewon R, Jones EG, Boonmee S et al. 2018a - Novel palmicolous taxa within Pleosporales: multigene phylogeny and taxonomic circumscription. Mycological Progress 17, 571-590.

Wanasinghe DN, Phukhamsakda C, Hyde KD, Jeewon R et al. 2018b - Fungal diversity notes 709839: taxonomic and phylogenetic contributions to fungal taxa with an emphasis on fungi on Rosaceae. Fungal diversity 89, 1-236. 